Article

\title{
Drought Stress Response of Turf-Type Perennial Ryegrass Genotypes in a Mediterranean Environment
}

\author{
Cristina Pornaro ${ }^{1, *(\mathbb{D})}$, Matteo Serena ${ }^{2}$, Stefano Macolino ${ }^{1(\mathbb{D})}$ and Bernd Leinauer ${ }^{2}(\mathbb{D}$ \\ 1 Department of Agronomy, Food, Natural resources, Animals, and the Environment, University of Padova, \\ 35020 Legnaro (PD), Italy; stefano.macolino@unipd.it \\ 2 Department of Extension Plant Science, New Mexico State University, Las Cruces, NM 88003, USA; \\ mserena@nmsu.edu (M.S.); leinauer@nmsu.edu (B.L.) \\ * Correspondence: cristina.pornaro@unipd.it
}

Received: 20 October 2020; Accepted: 16 November 2020; Published: 17 November 2020

\begin{abstract}
Perennial ryegrass is generally known as exhibiting poor drought tolerance with poor recuperative capacity. The objective of this study was to evaluate the effects of acute drought followed by a recovery period, on 11 perennial ryegrass varieties (Apple SGL, Azimuth, Barrage, Caddieshack, Double, Double Time, Ecologic, New Orleans, Pizzaz 2, Rainwater, Turfgold) and one tall fescue (Olympic Gold). The study was conducted in a rain-out structure to control water inputs. Green cover percentage, visual quality, color, normalized difference vegetation index (NDVI), and soil moisture were measured weekly. Eighty percent coverage was considered optimal and was reached only during the first two weeks of the drought period. Starting from the fourth week, a significant decrease in green cover was observed for most of the perennial ryegrass cultivars. However, 5 cultivars displayed a visual quality rate greater than 6 , which is considered acceptable during this period, while color ratings were recorded greater than 6 for 7 cultivars. At the end of the drought phase, the cultivar ' New Orleans' exhibited significantly greater green cover compared to most other perennial ryegrasses. The recovery of the grasses was slow and at the end of the experiment the variability in green cover between cultivars was greater than during the first week.
\end{abstract}

Keywords: recovery from drought stress; visual quality; green cover; GDD; ET

\section{Introduction}

Perennial ryegrass (Lolium perenne L.) is known for its pleasant color, attractiveness, persistency, and wear tolerance, making it one of the most used turfgrass species [1]. It is also recognized as one of the fastest establishing cool-season turfgrass, which explains its popularity for use on golf courses, sport fields, parks, and home lawns. One of the major drawbacks of perennial ryegrass is its poor drought and heat tolerance [2] compared to other cool-season grasses such as tall fescue [Lolium arundinaceum (Schreb.) Darbysh.]. As of 2007, there were more than 1200 varieties of perennial ryegrass registered in the world database, approximately 200 of which are commercially available [3]. More recently, new varieties that are labelled as drought tolerant have been released to the market [4].

In a Mediterranean environment, precipitation amounts often fall short of evapotranspiration requirements for perennial ryegrass, resulting in periods of drought conditions. [5]. The most critical period is summer, when temperatures are high, the evapotranspiration requirement is greatest, and precipitation is scarce.

Drought resistance mechanisms of turfgrass species fall into the categories of drought avoidance (or desiccation avoidance), drought tolerance, and drought escape [6-8]. Drought escape is described as the ability of a plant to complete a reproductive cycle before drought conditions arise, thus linking the survival of species to seeds [9]. Desiccation avoidance is classified as the ability to retain a relatively 
high internal water potential, and maintaining green color [6]. In contrast, drought tolerant turf species are able to maintain metabolic functions at reduced internal water potential and tissue dehydration in an attempt to minimize tissue damage while maintaining a negative tissue balance $[6,7,9,10]$. In general, desiccation-tolerant plant exhibits tissue dehydration and a general loss of color and quality during drought [10]. However, these grasses have shown great recuperative ability, once the soil and roots are re-hydrated [6]. Perennial ryegrass is generally classified as having poor drought tolerance mechanisms, with poor recuperative capacity [11].

Evaluation of turfgrass genotypes for drought resistance consists of imposing water stress over time. Water deficit can be generally identified as either acute or chronic [12]. Chronic drought stress is achieved by exposing turfgrasses to low amounts of irrigation water, generally below evapotranspiration demand, over an extended period of time, often referred as "deficit irrigation" $[13,14]$. This differs from acute stress, during which turfgrass plants are subjected to a period without water and the soil becomes increasingly dry, after which watering is resumed, and recovery is evaluated [12]. Generally, these types of studies are conducted in rain-out structures to prevent natural precipitation from confounding the results, and as such are costlier to conduct.

Although the newly released perennial ryegrass varieties are labelled as drought resistant, there is no information available on how these varieties have been evaluated, and they have not been compared regarding their drought tolerance. Acute stress would be the most appropriate type of test for a Mediterranean environment, in order to screen for drought resistance. Currently there is no information on the drought resistance of these recently released perennial ryegrass varieties, or how they would compare to tall fescue. Moreover, there is no information on the length of time these grasses can survive without supplemental irrigation in a dry climate. In this study we hypothesized that widely available perennial ryegrasses exhibit drought tolerance differences, but tall fescue would still outperform ryegrass during periods of drought. The objectives were to evaluate the effects of acute drought on 11 perennial ryegrass varieties and one tall fescue, and to evaluate the length of time they need to recover after a dry-down period in a Mediterranean environment.

\section{Materials and Methods}

A field study was conducted at the Experimental Agricultural Farm of the University of Padua located in Legnaro, northeastern Italy $\left(45^{\circ} 20^{\prime} \mathrm{N}, 11^{\circ} 57^{\prime} \mathrm{E} ; 8 \mathrm{~m}\right.$ a.s.l.). The soil at the site consisted of a coarse-silty, mixed, mesic, Oxyaquic Eutrudept [15] containing 14\% clay, $69 \%$ silt, and $17 \%$ sand, with a $\mathrm{pH}$ of $8.1,2.4 \%$ organic matter, a C-to-N ratio of 12.2, an Olsen P content of $29 \mathrm{mg} \mathrm{kg}^{-1}$, and an exchangeable $\mathrm{K}$ content of $140 \mathrm{mg} \mathrm{kg}^{-1}$. The climate of the area is classified as sub-humid, with a mean annual temperature of $12.3^{\circ} \mathrm{C}$ and annual rainfall of $820 \mathrm{~mm}$ mostly distributed from April to November.

The study was conducted from September 2016 to August 2017 and repeated from September 2017 to August 2018 in a rain-out structure $(16 \times 8 \mathrm{~m}$ wide) to control water inputs during the drought and recovery period of the experiment. Eleven perennial ryegrass cultivars ("Apple SGL", "Azimuth", "Barrage", "Caddieshack", "Double", "Doubletime", “Ecologic", "New Orleans", "Pizzazz 2", "Rainwater", "Turfgold") and one tall fescue cultivar ("Olympic Gold") were chosen from the cultivars currently available on the European market. All selected perennial ryegrass cultivars are labeled as high or medium drought-tolerant varieties. "Apple SGL", "New Orleans", and "Pizzazz 2" are considered stoloniferous types and "Double" and "Doubletime" as tetraploids. All other cultivars are traditional types. The tall fescue cultivar was introduced into the trial as a control since tall fescue is known to be more drought tolerant than perennial ryegrass [16]. Plots $1 \times 1.5 \mathrm{~m}$ in size were arranged in a completely randomized block design with three replications and seeded in September 2016 and September 2017. An evapotranspiration (ET) gauge meter (Spectrum Technology, Inc., Plainfield, IL, USA) was installed inside the structure to determine ET as a measure for irrigation requirement [17]. During establishment, turfgrasses were irrigated daily with 2-3 $\mathrm{mm}$ of water by means of an overhead sprinkler irrigation system. When full coverage was reached irrigation was provided weekly at $100 \%$ 
ET until the start of the experiment. Prior to seeding, the plot area was fertilized with $50 \mathrm{~kg} \mathrm{~N} \mathrm{ha}^{-1}, 150$ $\mathrm{kg} \mathrm{P}_{2} \mathrm{O}_{5} \mathrm{ha}^{-1}$, and $150 \mathrm{~kg} \mathrm{~K}_{2} \mathrm{O} \mathrm{ha}^{-1}$. Subsequently, a complete fertilizer low in phosphorus (15\% N-9\% $\mathrm{P}_{2} \mathrm{O}_{5}-15 \% \mathrm{~K}_{2} \mathrm{O}$ ) was applied at a rate of $200 \mathrm{~kg} \mathrm{~N} \mathrm{ha}^{-1} \mathrm{yr}^{-1}$ equally split into four applications $(30 \%$ in March, 20\% in May, 30\% in September, and 20\% in December). During the growing season plots were mowed once a week at a height of $43 \mathrm{~mm}$ with a rotary mower (Honda HRX $476 \mathrm{SX}$ E, Honda Motor Co. Ltd., Tokyo, Japan) and clippings were removed. The experiment consisted of two phases: the drought and the recovery phase. Prior to the drought phase, the area was irrigated to reach field capacity [18]. The drought phase was initiated on 15 June 2017 and on 31 May 2018, and lasted until the mean percentage green turf cover of the best performing cultivar was reduced to $60 \%$. Percentage green turf cover was measured by means of digital image analysis method described by [19]. The recovery phase started after the discontinuation of drought, with soil water content restored to saturation and irrigation applied weekly at $80 \%$ of evapotranspiration (ET). based on the ET gauge. Recovery was considered complete when the mean percentage green turf cover of the best performing cultivar reached $80 \%$. Recovery was concluded on 31 August in 2017 and on 23 August in 2018. Mean weekly air temperatures and relative humidity during the drought and recovery periods are reported in Figure 1. During the drought and the recovery periods, percentage green turf cover, normalized difference vegetation index (NDVI) (GreenSeeker Handheld Crop Sensor, Trimble Navigation Unlimited, Sunnyvale, CA), soil moisture [Field Scout TDR 300 Soil Moisture Meter (Spectrum Technology, Inc., Plainfield, IL, USA); 3 readings per plot, $0-7 \mathrm{~cm}$ depth], were measured weekly. Moreover, turf quality and color were visually rated weekly using a 1-9 scale $[20,21]$.

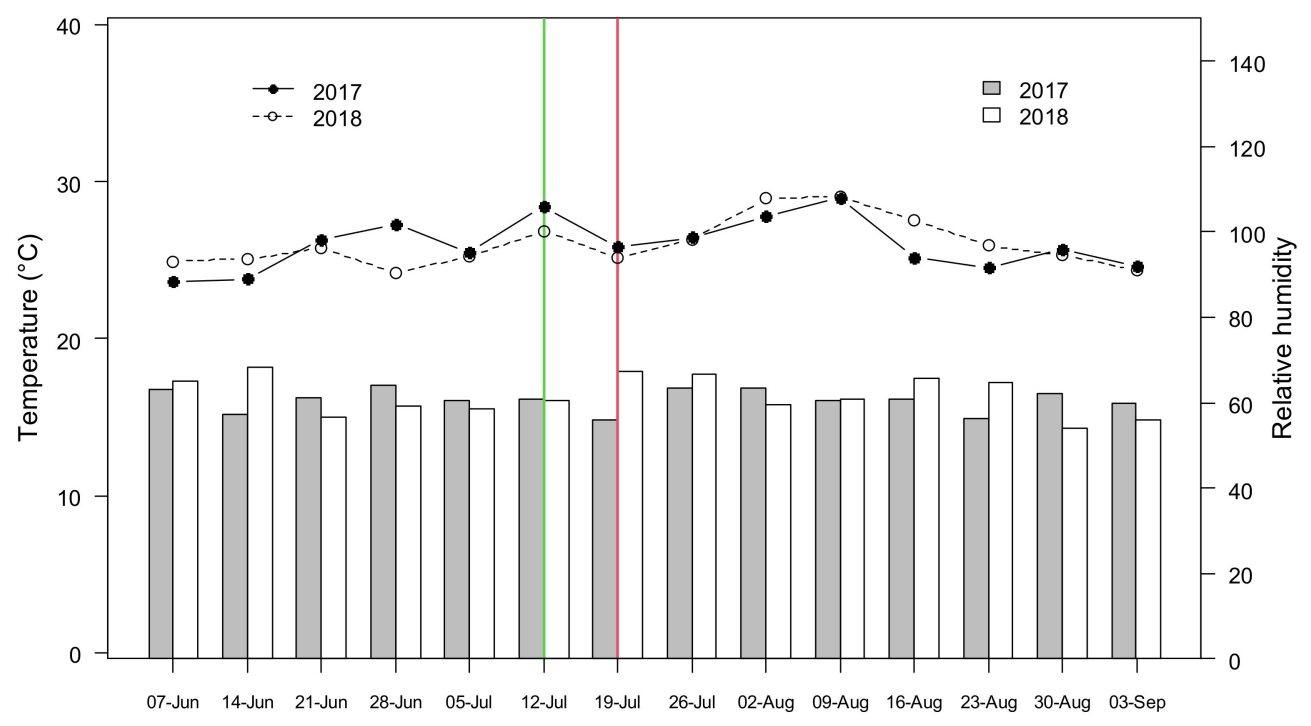

Figure 1. Weekly mean air temperature (lines) and relative humidity (bars) during the drought and recovery periods for the two experimental years (2017 and 2018). The red line indicates the date when the 2017 drought period was concluded (corresponding to sampling date number 6) whereas the green line represents the date when the 2018 drought period was concluded (corresponding to sampling date number 7).

A portable weather station (WatchDog 2700 Station, Spectrum Technologies, Inc., Plainfield, $\mathrm{IL}$, USA) was installed in the rain-out shelter and the relative humidity $(\%)$, air temperature $\left({ }^{\circ} \mathrm{C}\right)$, wind direction $\left(^{\circ}\right)$, and wind speed $\left(\mathrm{km} \mathrm{h}^{-1}\right)$ were measured hourly at a height of $1.5 \mathrm{~m}$ from September 2016 to August 2018. Monthly mean air temperatures over the entire study period are listed in Table 1. To test the effects of climate conditions on drought and recovery phases of the experiment, growing degree days (GDD) were calculated from the beginning of the year using average daily temperature and a $\mathrm{T}_{\mathrm{BASE}}$ of $3{ }^{\circ} \mathrm{C}$ [22], and evapotranspiration (ET) was calculated during the experimental period of the two years using data collected from the weather station. 
Table 1. Monthly mean air temperatures in a rain-out structure at the Agricultural Farm of Padova University in Legnaro (Padova, NE Italy) during the experimental period (September 2016-August 2018).

\begin{tabular}{cccc}
\hline & \multicolumn{3}{c}{ Air Temperature $\left({ }^{\circ} \mathbf{C}\right)$} \\
\cline { 2 - 4 } Month & $\mathbf{2 0 1 6}$ & $\mathbf{2 0 1 7}$ & $\mathbf{2 0 1 8}$ \\
\hline January & - & 1 & 6 \\
February & - & 6 & 4.2 \\
March & - & 11.1 & 7.7 \\
April & - & 14.4 & 16.9 \\
May & - & 19.2 & 21.7 \\
June & - & 25.1 & 24.9 \\
July & - & 26.7 & 26.8 \\
August & - & 26.4 & 26.8 \\
September & 20.7 & 17.8 & - \\
October & 13.3 & 13.7 & - \\
November & 9.2 & 8.1 & - \\
December & 3 & 2.8 & - \\
\hline
\end{tabular}

Analysis of variance was performed using a linear mixed effect model to test the effects of cultivar, sampling date, and their interaction on the measured parameters (green turf cover, NDVI, soil moisture, visual turf quality and color). The models were performed for repeated measurements, and year was included as random effect. The drought phase was five weeks in 2017 and six weeks in 2018, while the recovery period was six weeks in 2017 and five weeks in 2018. Since the drought treatment was not a fixed number of days but rather was based on the number of days since initiation of drought until percent green cover of the best performing cultivar was down to $60 \%$, to consider the second year as a real repetition of the first one, the models were centered at the sampling date which separated the drought period from the recovery. Green turf cover and NDVI data were square root transformed to achieve normality and homoscedasticity of the residuals and then transformed back to present results. The least significant difference test with the Bonferroni correction was used at the 0.05 probability level to identify significant differences among means. To exclude spatial correlation due to edge effect of the rain-out structure, longitudinal and latitudinal position of each plot were included as covariates ( $X$ and $Y$ positions) in the model. Statistical differences were determined by likelihood-ratio tests of models including and not including position as a covariate. For all parameters tested, position was found to be not significant based on Akaike's Information Criterion (AIC). Moreover, the effect of date in the models for each measured parameter (green turf cover, NDVI, soil moisture, visual quality and color) was replaced with day of the year (DOY), GDD, or ET and their statistical differences were determined based on AIC. All statistical analyses were performed using R version 3.4.0 [23] and additional packages nlme for fitting mixed models, and multcomp for post hoc comparisons.

\section{Results and Discussion}

The analysis of variance revealed a significant interaction between sampling date and cultivar for green turf cover, while the main effects of sampling date and cultivar were significant for NDVI, visual quality and color (Table 2). Soil moisture content was affected only by sampling date. 
Table 2. Results of analysis of variance, testing the effects of cultivar, sampling date and their interaction on percentage of green turf cover, normalized difference vegetation index (NDVI), soil moisture, visual quality (1-9 scale) and color (1-9 scale).

\begin{tabular}{cccc}
\hline & \multicolumn{3}{c}{ Sources } \\
\cline { 2 - 4 } Parameter & Cultivar & Sampling Date & Cultivar $\times$ Sampling Date \\
\hline Green turf cover & $* * *$ & $* * *$ & $* * *$ \\
NDVI & $* *$ & $* * *$ & $\mathrm{~ns}$ \\
Soil moisture & $\mathrm{ns}$ & $* *$ & $\mathrm{~ns}$ \\
Visual quality & $* * *$ & $* * *$ & $\mathrm{~ns}$ \\
Colour & $* * *$ & $* * *$ & $\mathrm{~ns}$ \\
\hline$* *, * * *$ Significant at the 0.01, and 0.001 probability level, respectively. n.s. Not significant at the 0.05 probability level.
\end{tabular}

At the beginning of the experiment, green cover of all cultivars ranged between 78 and $93 \%$ (Figure 2). For the first three weeks no statistical differences among cultivars were noted. Starting from the fourth week, a significant decrease in green turf cover was observed for most of the perennial ryegrass cultivars (Azimuth, Barrage, Caddieshack, Double, Doubletime, Ecologic). This decrease continued until the seventh week, in which 'New Orleans' had a significantly higher green turf cover (58\%) compared with 'Apple', 'Azimuth', 'Barrage', 'Caddieshack', 'Doubletime', 'Ecologic', 'Pizzazz 2 ', and 'Turfgold', which displayed a percentage ranging from 38 to $44 \%$. 'New Orleans' has been reported to produce stolons, especially in early summer following establishment [24]. The presence of stolons could explain its greater resistance to drought stress compared to other non-creeping cultivars. It has been well documented that cold tolerance and winter hardiness of warm-season grasses is related to carbohydrate content stored in stolons and rhizomes $[25,26]$. Stolons may also help plants under drought stress conditions [27]. Chai et al. [28] documented that the drought stress caused a decrease of non-structured carbohydrates in reserve structures such as crowns. At the onset of the experiment percent green cover of the tall fescue variety 'Olympic Gold' was $90 \%$ or higher, but this decreased significantly from week four through seven, dropping as low as $78 \%$.

Limited information is available on the relationship between volumetric water content and green turfgrass coverage. At lower soil water content, the plants close their stomata and transpiration is reduced compared to well-watered conditions [29]. A long period of time under reduced soil volumetric water content will result in lower canopy density, decrease in coverage and reduced turfgrass quality [30-32]. Differences in percent green turfgrass coverage could be related to water availability remaining in the soil profile, as drought tolerance of perennial ryegrass is based on low internal water potential [10]. The soil moisture was not affected by cultivar, and its content for the first three weeks was above $24 \%$ averaged over all varieties (Table 3), which was enough to meet the water requirements of the turfgrasses. Starting from the fourth week, when the reduction in green cover was observed, soil moisture content dropped to $21 \%$, and on week six it was $15 \%$ (Table 3 ). The stress exerted on the plants was confirmed by the NDVI. The values averaged over all varieties ranged from 0.83 at the beginning of the experiment to 0.64 at the end of the drought period (Table 3). From week two until the end of the drought period NDVI values progressively decreased, and the optimal cover percentage of $80 \%$ was maintained only in the first two weeks of the drought period. However, visual quality and color, which progressively decreased during the drought period (Table 3), was considered adequate until the fourth week of the drought period. In Mediterranean regions, visual quality ratings of at least 7 are common for properly watered perennial ryegrass [5,33]. Our results suggested that an average visual quality rating of 7 can be maintained in turfs constituted by perennial ryegrass for about two weeks without irrigation in a coarse-silty soil. These results are probably linked to the water holding capacity of the silty-loam soil of the study area [34]. This is confirmed by soil moisture (Table 3) measurements. It took three weeks to get below $20 \%$ when irrigation was suspended. 


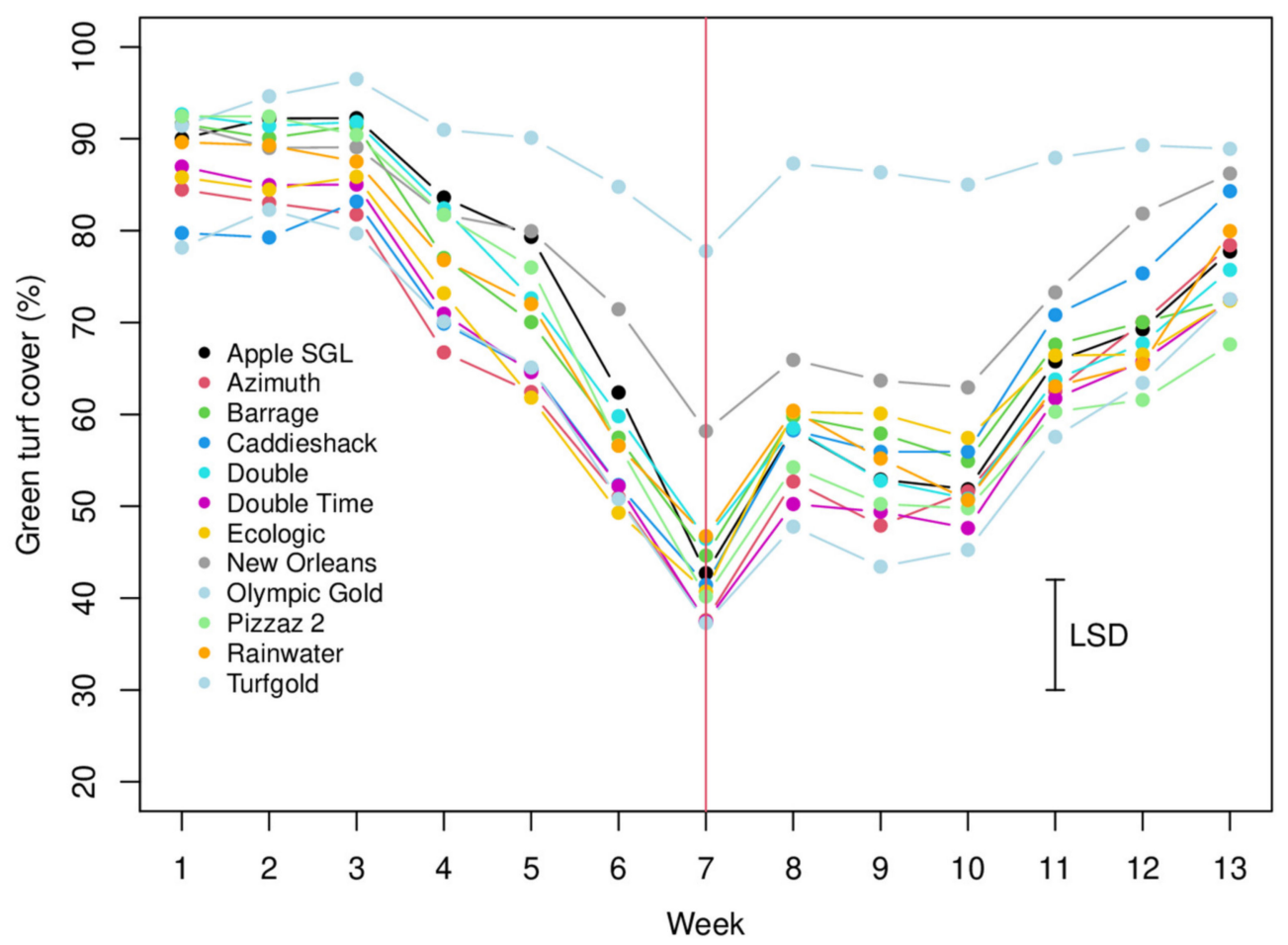

Figure 2. Percentage green cover of 11 perennial ryegrass cultivars (Apple SGL, Azimuth, Barrage, Caddieshack, Double, Doubletime, Ecologic, New Orleans, Pizzazz 2, Rainwater, Turfgold) and a tall fescue cultivar (Olympic Gold) during the experimental period. The sampling dates to the left of the vertical red line represent the drought period, while to the right, data corresponding to the recovery period are shown. Data were averaged over two years (2017 and 2018) and 3 replications. Error bar represents the least significant difference $(p=0.05)$ for comparing means.

Table 3. Effect of sampling date on soil moisture (\%), normalized difference vegetation index (NDVI), visual quality (1-9 scale), and color (1-9 scale) of 11 perennial ryegrass cultivars (Apple SGL, Azimuth, Barrage, Caddieshack, Double, Doubletime, Ecologic, New Orleans, Pizzazz 2, Rainwater, Turfgold) and one tall fescue cultivar (Olympic Gold).

\begin{tabular}{cccccccc}
\hline & $\begin{array}{c}\text { Sampling Date } \\
\text { (Week) }\end{array}$ & GDD & Cumulative ET & Soil Moisture & NDVI & Visual Quality & Colour \\
\hline & 1 & 1682 & 4.92 & 42.56 & 0.83 & 6.94 & 6.78 \\
& 2 & 1886 & 20.49 & 34.54 & 0.84 & 6.85 & 6.72 \\
Drought period & 3 & 2068 & 55.38 & 24.09 & 0.81 & 6.76 & 6.65 \\
& 4 & 2255 & 91.66 & 20.71 & 0.77 & 6.33 & 6.32 \\
& 5 & 2426 & 124.05 & 17.69 & 0.75 & 6.03 & 6.11 \\
& 6 & 2617 & 160.52 & 15.37 & 0.69 & 5.44 & 5.44 \\
& 7 & 2785 & 192.76 & 15.16 & 0.64 & 4.83 & 4.78 \\
\hline \multirow{5}{*}{ Recovery period } & 8 & 2968 & 225.85 & 21.89 & 0.68 & 5.29 & 5.14 \\
& 9 & 3175 & 263.04 & 19.98 & 0.69 & 5.49 & 5.43 \\
& 10 & 3564 & 297.92 & 23.94 & 0.71 & 5.67 & 5.65 \\
& 11 & 3376 & 331.35 & 22.92 & 0.76 & 6.21 & 6.14 \\
& 12 & 3744 & 351.79 & 21.48 & 0.78 & 6.35 & 6.24 \\
& 13 & 3963 & 373.67 & 20.03 & 0.82 & 6.52 & 6.38 \\
\hline
\end{tabular}

The expected recovery of percent green cover in response to irrigation from week seven to eight was only observed in 'Barrage', 'Double', 'Doubletime', and 'Caddieshack' (Figure 2). From week eight through ten, percent green cover remained unchanged, which is an indication of poor recuperative ability during times of higher temperatures (Figure 1). It confirms findings of [11] who also documented that the perennial ryegrass does not recover well from drought stress. Only from week ten until the 
end of the experiment all perennial ryegrass cultivars displayed a significant increase of green cover. At the end of the experiment, the variability in percent green cover between cultivars was higher than during the first week. 'Pizzazz 2' showed lower green coverage than 'Caddieshack', 'New Orleans', and 'Olympic Gold', which reached green cover higher than $80 \%$. From week eight through thirty, percent green cover of 'Olympic Gold' remained stable at around $90 \%$. NDVI values progressively increased over the entire recovery period (Table 3), as did visual quality ratings and color. Similar to green turf cover, a significant increase of NDVI was observed during the first week of recovery, and then again during week 5 when values rose to 0.82 . By the end of the recovery period, mean visual quality and color ratings for all cultivars were still not as high as they were at the beginning of the experiment (6.5 and 6.4, respectively). Generally, a soil moisture of greater than 20\% (Figure 1) seemed to be sufficient to ensure green turf cover recovery (Table 3), but it was not sufficient to achieve optimal visual quality.

The effect of cultivar on NDVI, visual quality and color is presented in Figure 3. Among perennial ryegrass cultivars, only 'Apple SGL' and 'Rainwater' showed similar NDVI values to those of 'Olympic Gold' tall fescue (Figure 3a) while the other cultivars displayed lower values. However, these differences in NDVI are not reflected in visual quality, as 'New Orleans' displayed significantly higher ratings than the other cultivars (Figure 3b). In contrast, 'Barrage' and 'Turfgold' displayed the lowest visual quality ratings. With regards to color, 'Pizzazz 2' and 'Apple SGL' were in the highest score group while 'Turfgold', 'Barrage' and 'Ecologic' exhibited the lowest ratings (Figure 3c).

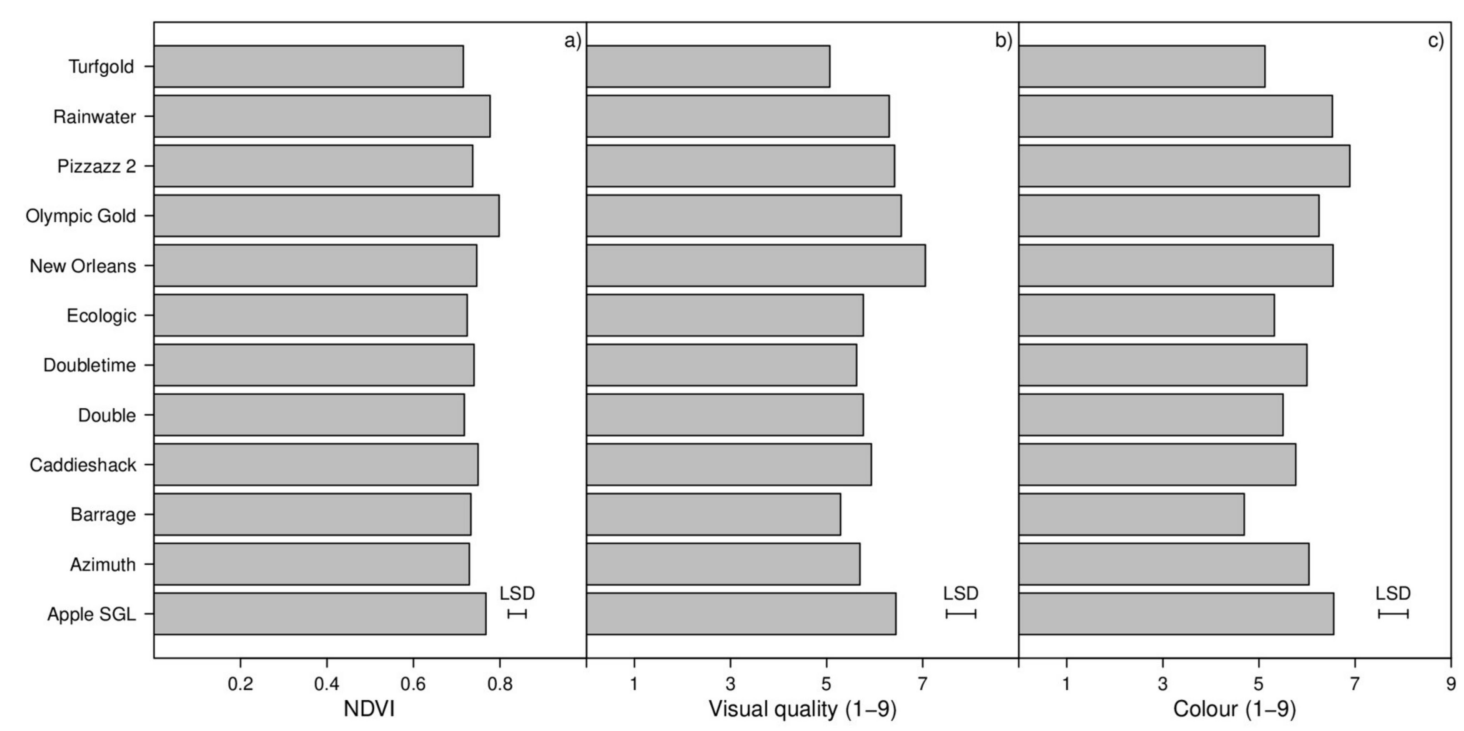

Figure 3. Effect of cultivar on NDVI (a), visual quality (b), and color (c) of 11 perennial ryegrass cultivars (Apple SGL, Azimuth, Barrage, Caddieshack, Double, Doubletime, Ecologic, New Orleans, Pizzazz 2, Rainwater, Turfgold) and 1 tall fescue cultivar (Olympic Gold). Error bar represents the least significant difference $(p=0.05)$ for comparing means.

Including the variables DOY, GDD, and ET in the models instead of sampling date and comparing the three models, based on AIC values, we determined the best performing model to be the one that included GDD (Table 4). This suggests that higher temperatures accelerated turfgrass decline and delayed recovery rather than ET, which is affected by a suite of variables, such as solar radiation, temperature, wind, and relative humidity. Our results highlight the importance of GDD as the main variable to be included in modelling perennial ryegrass stress resistance and recovery. We expected that drought stress would be mainly affected by ET, but our results did not reveal such an effect. The high relative humidity of the study area (Figure 1) might have reduced ET delaying the onset of drought symptoms. These findings are corroborated by [35], who reported turfgrass ET in humid environments about 40 to $60 \%$ lower than for the same cultivar in an arid environment. 
Table 4. Model fit statistics for the analysis of models applied to each measured parameter (green turf cover, NDVI, soil moisture, visual quality, and color) performed using sampling date, day of the year (DOY), GDD, or ET.

\begin{tabular}{ccccc}
\hline Parameter & Variable & AIC & BIC & -2 Res Log-Likelihood \\
\hline \multirow{5}{*}{ Green cover } & Sampling date & -305 & 435 & 311 \\
& DOY & -741 & -614 & 398 \\
& GDD & -665 & -537 & 359 \\
& ET & -708 & -580 & 381 \\
\hline \multirow{5}{*}{ Soil moisture } & Sampling date & 2911 & 3657 & -1299 \\
& DOY & 3289 & 3417 & -1617 \\
& GDD & 3378 & 3498 & -1658 \\
& ET & 3332 & 3460 & -1639 \\
\hline \multirow{5}{*}{ NDVI } & Sampling date & -984 & -247 & 679 \\
& DOY & -1110 & -982 & 582 \\
& GDD & -1029 & -901 & 541 \\
\hline \multirow{5}{*}{ Visual quality } & ET & -1087 & -965 & -312 \\
& Sampling date & 545 & 798 & -407 \\
& DOY & 1021 & 915 & -375 \\
& GDD & 943 & 852 & -391 \\
\hline \multirow{5}{*}{ Colour } & ET & 998 & 876 & -329 \\
& Sampling date & 565 & 780 & -409 \\
& DOY & 1037 & 913 & -381 \\
& GDD & 946 & 863 & -397 \\
\hline
\end{tabular}

\section{Conclusions}

During a seven week-long period of drought conditions, all tested perennial ryegrass cultivars maintained acceptable overall quality for two weeks, but separation in quality and other measured parameters occurred during the remaining five weeks. "New Orleans" showed greater green cover and visual quality than the other perennial ryegrass cultivars, especially at the end of the drought period and in the recovery phase. That said, the best performing grass in the study was tall fescue "Olympic Gold". With the exception of visual quality, all cultivars showed evidence of recovery from severe drought stress based on percent green cover and NDVI six weeks after the drought period ended. Not all cultivars displaying greater green cover and quality at the beginning of the experiment recovered best from drought stress. We also demonstrated that in a humid climate GDD is a more useful tool to predict the response of plants to drought than ET.

Author Contributions: Conceptualization, S.M. and B.L.; methodology, S.M. and B.L.; software, C.P.; validation, S.M. and B.L.; formal analysis, C.P. and M.S.; investigation, C.P.; resources, S.M. and B.L.; data curation, C.P and M.S.; writing-original draft preparation, C.P. and M.S.; writing-review and editing, C.P, M.S., S.M., and B.L.; visualization, C.P.; supervision, S.M. and B.L.; project administration, S.M. and B.L.; funding acquisition, S.M. All authors have read and agreed to the published version of the manuscript.

Funding: This research was funded by Padana Sementi Elette s.r.l.

Acknowledgments: The authors would like to thank Rossana Sallenave for her editing efforts which greatly improved the manuscript. Michele Dal Maso's technical support in the field is also greatly appreciated.

Conflicts of Interest: The authors declare no conflict of interest.

\section{References}

1. Meyer, W.A.; Funk, C.R. Progress and benefits to humanity from breeding cool-season grasses for turf. Contrib. Breed. Forage Turf Grasses 1989, 15, 31-48.

2. Turgeon, A.J. Turfgrass Management, 7th ed.; Prentice Hall: Englwood Cliffs, NJ, USA, 2005. 
3. Bonos, S.A. Commerically available cool-season turfgrass species and cultivar resource list. Rutgers Turfgrass Proc. 2007, 38, 159-178.

4. Perennial Ryegrass. Available online: https://www.tgwca.org/perennial-ryegrass.html (accessed on 23 September 2020).

5. Pornaro, C.; Barolo, E.; Rimi, F.; Macolino, S.; Richardson, M. Performance of various cool-season turfgrasses as influenced by simulated traffic in northeastern Italy. Eur. J. Hortic. Sci. 2016, 81, 27-36. [CrossRef]

6. Fry, J.; Huang, B. Applied Turfgrass Science and Physiology; John Wiley \& Sons: Hoboken, NJ, USA, 2004.

7. Kopp, K.L.; Jiang, Y. Turfgrass water use and physiology. Turfgrass Biol. Use Manag. 2013, 56, 319-345.

8. Shearman, R.C.; Kenna, M.P. Developing turfgrasses with drought resistance and heat and salinity stress tolerance. In Turfgrass Water Conservation, 2nd ed.; Cockerham, S.T., Leinauer, B., Eds.; UCANR Publication: Davis, CA, USA, 2011; Volume 3523, pp. 31-42.

9. Beard, J.B. Turfgrass water stress: Drought resistance components, physiological mechanisms, and species-genotype diversity. In Proceedings of the 6th International Turfgrass Research Conference, Tokyo, Japan, 31 July-5 August 1989; Japanese Society of Turfgrass Science: Tokyo, Japan, 1989.

10. Huang, B. Mechanisms and strategies for improving drought resistance in turfgrass. Acta Hortic. 2008, 783, 221. [CrossRef]

11. Wilkins, P.W. Breeding perennial ryegrass for agriculture. Euphytica 1991, 52, 201-214. [CrossRef]

12. Richardson, M.D.; Karcher, D.E.; Hignight, K.; Hignight, D. Irrigation requirements of tall fescue and Kentucky bluegrass cultivars selected under acute drought stress. Appl. Turfgrass Sci. 2012, 9, 1-13.

13. Feldhake, C.M.; Danielson, R.E.; Butler, J.D. Turfgrass evapotranspiration. 11. Responses to deficit irrigation 1. Agron. J. 1984, 76, 85-89. [CrossRef]

14. Kneebone, W.R.; Kopec, D.M.; Mancino, C.F. Water requirements and irrigation. Turfgrass 1992, 32, 441-472.

15. Morari, F. Drainage flux measurement and errors associated with automatic tension-controlled suction plates. Soil Sci. Soc. Am. J. 2006, 70, 1860-1871. [CrossRef]

16. Sheffer, K.M.; Dunn, J.H.; Minner, D.D. Summer drought responses and rooting depth of three cool-season turfgrasses. HortSci. 1987, 22, 296-297.

17. Jaafar, H.H.; Ahmad, F. Evaluating atmometer performance for estimating reference evapotranspiration in ventilated and unventilated greenhouses. J. Irrig. Drain. Eng. 2018, 144, 04018014. [CrossRef]

18. Dal Ferro, N.; Cocco, E.; Lazzaro, B.; Berti, A.; Morari, F. Assessing the role of agri-environmental measures to enhance the environment in the Veneto Region, Italy, with a model-based approach. Agr. Ecosyst. Environ. 2016, 232, 312-325. [CrossRef]

19. Richardson, M.D.; Karcher, D.E.; Purcell, L.C. Quantifying turfgrass cover using digital image analysis. Crop. Sci. 2001, 41, 1884-1888. [CrossRef]

20. Krans, J.V.; Morris, K. Determining a profile of protocols and standards used in the visual field assessment of turfgrasses: A survey of national turfgrass evaluation program-sponsored university scientists. Appl. Turfgrass Science 2007, 4, 1-6. [CrossRef]

21. Leinauer, B.; Van Leeuwen, D.M.; Serena, M.; Schiavon, M.; Sevostianova, E. Digital image analysis and spectral reflectance to determine turfgrass quality. Agron. J. 2014, 106, 1787-1794. [CrossRef]

22. Studer, B.; Jensen, L.B.; Hentrup, S.; Brazauskas, G.; Kölliker, R.; Lübberstedt, T. Genetic characterisation of seed yield and fertility traits in perennial ryegrass (Lolium perenne L.). Theor. App. Genet. 2008, 117, 781-791. [CrossRef]

23. R Development Core Team. R 3.3. 4. R Project for Statistical Computing; R Development Core Team: Vienna, Austria, 2017.

24. Pornaro, C.; Menegon, A.; Macolino, S. Stolon development in four turf-type perennial ryegrass cultivars. Agron. J. 2018, 110, 2159-2164. [CrossRef]

25. Pornaro, C.; Macolino, S.; Richardson, M.D. Rhizome and stolon development of bermudagrass cultivars in a transition-zone environment. Acta Agric. Scand. Section B Soil Plant Sci. 2019, 69, 657-666. [CrossRef]

26. Schiavon, M.; Macolino, S.; Leinauer, B.; Ziliotto, U. Seasonal changes in carbohydrate and protein content of seeded bermudagrasses and their effect on spring green-up. J. Agron. Crop. Sci. 2016, 202, 151-160. [CrossRef]

27. Karsten, H.D.; MacAdam, J.W. Effect of drought on growth, carbohydrates, and soil water use by perennial ryegrass, tall fescue, and white clover. Crop. Sci. 2001, 41, 156-166. [CrossRef] 
28. Chai, Q.; Jin, F.; Merewitz, E.; Huang, H. Growth and physiological traits associated with drought survival and post-drought recovery in perennial turfgrass species. J. Am. Soc. Hortic. Sci. 2010, 135, 125-133. [CrossRef]

29. Huang, B. Turfgrass water requirements and factors affecting water usage. Water quality and quantity issues for turfgrass in urban landscapes. Council Agric. Sci. Technol. Spec. Publ. 2008, 27, 193-205.

30. Biran, I.; Bravdo, B.; Bushkin-Harav, I.; Rawitz, E. Water consumption and growth rate of 11 turfgrasses as affected by mowing height, irrigation frequency, and soil moisture. Agron. J. 1981, 73, 85-90. [CrossRef]

31. Kim, K.S. Comparative Evapotranspiration Rates of Thirteen Turfgrasses Grown under both Non-Limiting Soil Moisture and Progressive Water Stress Conditions. Master's Thesis, Texas A\&M University, College Station, TX, USA, 1983.

32. DaCosta, M.; Huang, B. Minimum water requirements for creeping, colonial, and velvet bentgrass under fairway conditions. Crop Sci. 2006, 46, 81-89. [CrossRef]

33. Demirel, K.; Kavdır, Y. Effect of soil water retention barriers on turfgrass growth and soil water content. Irrig. Sci. 2013, 31, 689-700. [CrossRef]

34. Handreck, K.A.; Black, N.D.; Black, N. Growing Media for Ornamental Plants and Turf; UNSW Press: Kensington, UK, 2010; p. 551.

35. Carrow, R.N. Drought resistance aspects of turfgrasses in the Southeast: Evapotranspiration and crop coefficients. Crop Sci. 1995, 35, 1685-1690. [CrossRef]

Publisher's Note: MDPI stays neutral with regard to jurisdictional claims in published maps and institutional affiliations.

(C) 2020 by the authors. Licensee MDPI, Basel, Switzerland. This article is an open access article distributed under the terms and conditions of the Creative Commons Attribution (CC BY) license (http://creativecommons.org/licenses/by/4.0/). 